\title{
The activity of $\sigma^{\mathrm{E}}$, an Escherichia coli heat-inducible $\sigma$-factor, is modulated by expression of outer membrane proteins
}

\author{
Joan Mecsas, Pierre E. Rouviere, ${ }^{1}$ James W. Erickson, ${ }^{2}$ Timothy J. Donohue, and Carol A. Gross ${ }^{1,3}$ \\ Department of Bacteriology, University of Wisconsin-Madison, Madison, Wisconsin 53706 USA
}

\begin{abstract}
$\sigma^{\mathrm{E}}$ and $\sigma^{32}$ are two heat- and ethanol-inducible $\sigma$-factors in Escherichia coli. The $\sigma^{32}$ regulon is also induced by unfolded and misfolded proteins in the cytoplasm, and the function of many of the proteins in the $\sigma^{32}$ regulon is to bind to cytoplasmic proteins and assist them in folding or unfolding. To further understand the function of the $\sigma^{\mathrm{E}}$ regulon, we searched for mutants that affected $\sigma^{\mathrm{E}}$ activity. Our results indicate that a signal generated by expression of outer membrane proteins modulates $\sigma^{E}$ activity. Specifically, $\sigma^{E}$ activity is induced by increased expression of OMPs and is reduced by decreased expression of OMPs. In addition, mutations that cause misfolded OMPs induce $\sigma^{\mathrm{E}}$ activity. This signal is generated after the fate of OMPs and periplasmic proteins diverge in the secretory pathway and is not the result of an accumulation of OMP precursors in the cytoplasm. Our results indicate that this effect of OMPs is specific to the $\sigma^{\mathrm{E}}$ regulon, because none of the above mutations affect $\sigma^{32}$ activity. We propose that the $\sigma^{E}$ regulon is involved in processes that occur in extracytoplasmic compartments and that these two heat-inducible regulons may have distinct but complementary roles of monitoring the state of proteins in the cytoplasm $\left(\sigma^{32}\right)$ and outer membrane $\left(\sigma^{\mathrm{E}}\right)$.
\end{abstract}

[Key Words: $\sigma$-Factors; protein export; outer membrane proteins; heat shock; $\sigma^{\mathrm{E}}$ ]

Received September 13, 1993; revised version accepted October 14, 1993.

In bacterial cells the $\sigma$-subunit directs RNA polymerase to initiate transcription at promoter sites on the DNA (Burgess et al. 1969). The primary $\sigma$-factor in the cell is responsible for transcription of most genes during exponential growth. In addition, alternative $\sigma$-factors direct transcription of sets of genes whose products are needed for specific functions, such as sporulation, nitrogen fixation, or flagella synthesis (Gross et al. 1992). Alternative $\sigma$-factors are often activated by changes in environmental or cellular conditions that generate morphological and/or molecular cues, signaling the need for the gene products in the regulon under control of a particular $\sigma$-factor. Elucidation of these signal-transduction pathways provides insights about global control of gene activity in prokaryotic cells.

The activity of two Escherichia coli alternative $\sigma$-factors, $\sigma^{32}$ and $\sigma^{\mathrm{E}}\left(\sigma^{24}\right)$, increases after temperature upshift or exposure to ethanol /Grossman et al. 1984; Erickson et al. 1987; Straus et al. 1987; Erickson and Gross 1989; Wang and Kaguni 1989). RNA polymerase (E) containing $\sigma^{32}\left(\mathrm{E}^{32}\right)$ transcribes the heat shock genes with products that consist primarily of chaperones and proteases.

Present addresses: ${ }^{1}$ Department of Oral Biology, University of California San Francisco, San Francisco, California 94143 USA; ${ }^{2}$ Department of Molecular and Cell Biology, University of California, Berkeley, Berkeley, California 94720 USA.

${ }^{3}$ Corresponding author.
These heat shock proteins function to process partially folded proteins in the cytoplasm and target them for secretion, proteolysis, or refolding (Straus et al. 1988; Hoffmann et al. 1992; Martin et al. 1992; Wild et al. 1992a); to aid in assembly and disassembly of complex protein structures (Alfano and McMacken 1989; Dodson et al. 1989; Zylicz et al. 1989); and to protect the cell from severe stresses (i.e., $10 \%$ ethanol and $50^{\circ} \mathrm{C}$ ) (Neidhardt and VanBogelen 1987). Interestingly, under conditions of severe stress, only $\mathrm{E}^{\mathrm{E}}$ transcribes $\mathrm{rpoH}$ (Erickson et al. 1987), the gene encoding $\sigma^{32}$. Because $\sigma^{32}$ is unstable (Straus et al. 1987), continued transcription of $r p o H$ by $\mathrm{E} \sigma^{\mathrm{E}}$ is probably essential for cell survival under these conditions. Thus, $\sigma^{\mathrm{E}}$ was initially thought to be a supplementary heat shock $\sigma$-factor that functioned to maintain high concentrations of $\sigma^{32}$ during severe conditions.

The only other $E$. coli gene known to be transcribed by $\mathrm{E}^{\mathrm{E}}{ }^{\mathrm{is}} \operatorname{degP}(\mathrm{htrA})$ (Erickson and Gross 1989), which encodes a periplasmic endopeptidase essential at temperatures above $42^{\circ} \mathrm{C}$ (Lipinska et al. 1988, 1989, 1990; Strauch and Beckwith 1988; Strauch et al. 1989). Although the physiological substrates of DegP have not been identified, it can degrade colicin A /Cavard et al. 1989 ). Because $E \sigma^{\mathrm{E}}$ is the only form of RNA polymerase that transcribes $\operatorname{deg} P$, the requirement for $\operatorname{DegP}$ at $42^{\circ} \mathrm{C}$ is circumstantial evidence that $\sigma^{\mathrm{E}}$ plays an essential role in protecting cells from stress caused by high tempera- 


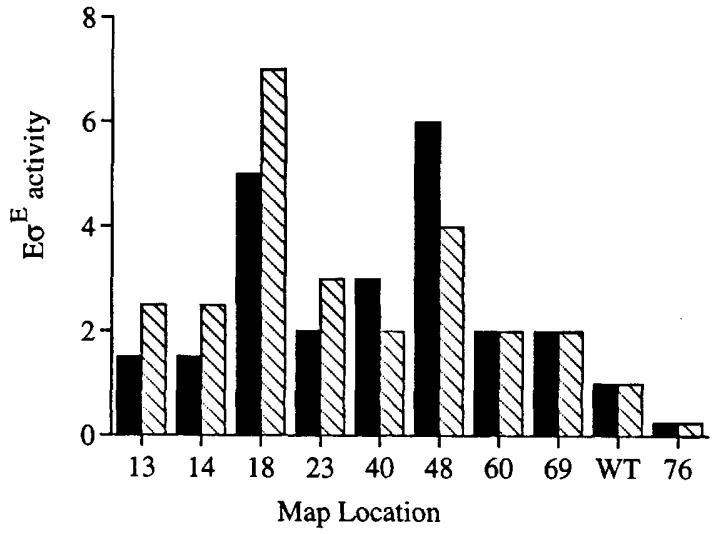

Figure 1. Changes in $\mathrm{E}^{\mathrm{E}}$ activity at the $r p o H P 3$ and $\operatorname{deg} P$ promoters resulting from pISE plasmids or mini-Mu insertion (dse). $\mathrm{E \sigma}^{\mathrm{E}}$ activity at $r p o H P 3$ was assayed by monitoring $\beta$-galactosidase activity from a single copy $\Phi \lambda[r p o H P 3-l a c Z]$ fusion (solid bars). E ${ }^{\mathrm{E}}$ activity at the $\operatorname{deg} P$ promoter was assayed by S1 mapping of RNA (hatched bars). Assays were done in the CAG16052 strain background for the pISE strains (map positions 13, 14, 18, $23,40,48,60$, and 69| and in MC1061 $\Phi \lambda[$ [poHP3-lacZ] for the dse allele (map position 76 ). The wild-type values were obtained from CAG16052 + pEG5005 for the pISE strains and MC1061Ф $\lambda$ [rpoHP3-lacZ] for the $d s e$ strain. All values were normalized to wild type and are averages of measurements made at least twice.

tures. However, the periplasmic location of DegP suggests that the E $\sigma^{\mathrm{E}}$ regulon may protect extracytoplasmic compartments from stress.

The experiments in this paper focus on identifying the signals that modulate $\mathrm{E}^{\mathrm{E}}$ activity. We find that the activity of $E \sigma^{\mathbf{E}}$ increases when outer membrane proteins (OMPs) are overproduced and decreases when they are underproduced. Additional experiments suggest that the signal generated by OMPs is likely to originate in the periplasm or at the outer membrane (OM). This signal, unlike heat or ethanol, does not affect $E \sigma^{32}$ activity. We suggest that $\sigma^{\mathrm{E}}$ responds to signals in the extracytoplasmic compartments of the bacterial cell.

\section{Results}

\section{Identification of positive regulators of $E \sigma^{E}$ activity}

To elucidate the role of $\sigma^{\mathrm{E}}$ in $E$. coli cell physiology, we used two genetic strategies to identify potential positive regulators of $\mathrm{E \sigma}^{\mathrm{E}}$ activity. The first strategy was predicated on the rationale that increasing the copy number of genes encoding positive regulators of $\mathrm{E \sigma}^{\mathrm{E}}$ will increase $\mathrm{E} \sigma^{\mathrm{E}}$ activity. The second strategy was based on the rationale that loss-of-function mutations in positive regulators will decrease E $\sigma^{\mathrm{E}}$ activity. To monitor E $\sigma^{\mathrm{E}}$ activity, gene fusions containing only 37 bases of the rpoHP3 promoter were used to express various reporter genes. Thus, changes in transcription from these fusions should result solely from changes in $\mathrm{E \sigma}^{\mathrm{E}}$ activity at the promoter.

To identify genes that increased $E \sigma^{\mathrm{E}}$ activity when present in multicopy, a random plasmid library of $E$. coli DNA (Groisman and Casadaban 1986) was introduced into a reporter strain in which expression of chloramphenicol acetyltransferase is driven from rpoHP3. Cells growing on higher concentrations of chloramphenicol than the parental strain could contain plasmids that increased sigma E activity (pISE). The inserts on those plasmids were mapped to nine regions of the $E$. coli genome (Table 1) by hybridization to the Kohara phage gene bank (Kohara et al. 1987). Because most of the DNA regions were isolated only once, more genes may exist that increase $\mathrm{E}^{\mathrm{E}}$ activity when cloned on a multicopy plasmid. The increase in $\mathrm{E}^{\mathrm{E}}$ activity for one representative of each region was verified and quantified by examining expression from two different $E \sigma^{\mathrm{E}}$ promoters. Plasmids caused a 1.5- to 7-fold increase in E ${ }^{\mathrm{E}}$ activity, and, in general, the increase in expression at $r p o H P 3$ and $\operatorname{deg} P$ were similar (Fig. 1).

To identify genes that decreased $\mathrm{E}^{\mathrm{E}}$ activity when inactivated, transposon mutagenesis with mini-Mu (Castilho et al. 1984) was performed in a reporter strain in which expression of galK is driven from rpoHP3. Cells with normal expression of $\mathrm{E}^{\mathrm{E}}$ are red on MacConkeygalactose plates, whereas those with decreased $\mathrm{E}^{\mathrm{E}}$ activity should be white. In addition, cells with decreased $E \sigma^{E}$ activity should be temperature sensitive as a result of decreased transcription of $\operatorname{deg} P$, which is required for growth at high temperature. This screen identified one locus, dse (decreased sigma E), mapping to $76 \mathrm{~min}$ by $\mathrm{P} 1$ transduction and to Kohara phage $619-621$ by hybridization (Table 1). The dse insertion caused a fourfold decrease in expression at both the rpoHP3 and $\operatorname{degP}$ promoters (Fig. 1).

Table 1. Mapping of loci altering E$\sigma^{E}$ activity

\begin{tabular}{lccl}
\hline Locus $^{\mathrm{a}}$ & $\begin{array}{l}\text { Number } \\
\text { of isolates }\end{array}$ & $\begin{array}{l}\text { Kohara } \\
\text { phage }^{\mathrm{b}}\end{array}$ & Known genes \\
\hline ise13 & 1 & $160-162$ & ompT, env, appY \\
ise14 & 1 & 168 & $\operatorname{lip} A$ \\
ise18 & 12 & $205-206$ & ompX \\
ise23 & 1 & $225-226$ & \\
ise40 & 1 & $335-336$ & htpX, prc \\
ise48 & 2 & 373 & ompC \\
ise60 & 1 & $458-459$ & argA \\
ise69 & 1 & $518-519$ & mtrA, deaD, pnp, yhb \\
dse76 & 16 & $619-621$ & ompR, envZ, bioH, pckA
\end{tabular}

${ }^{a}$ The number indicates the map position of the locus on $E$. coli chromosome; (ise) increased $\sigma^{\mathrm{E}}$ activity; (dse) decreased $\sigma^{\mathrm{E}}$ activity.

bPlasmids were mapped to Kohara phage (see Materials and methods)

${ }^{\mathrm{c}}$ Genes mapping to these phage were identified using GeneScape (Bouffard et al. 1992).

${ }^{\mathrm{d}}$ Genes in boldface type encode proteins that are located in the outer membrane, or positive regulators of OMPs.

'Cells containing pISE14 were mucoid.

fompX is described in J. Mecsas, R. Welch, J.W. Erickson, and C.A. Gross (in prep). 


\section{Overproduction of OMPs increases E$\sigma^{E}$ activity}

A number of loci were identified that increased $\mathrm{E}^{\mathrm{E}}$ activity when present in multicopy. We initially focused on characterizing the insert on plasmid pISE 18 because this region of the genome was isolated independently 12 times and gave one of the largest (five- to sevenfold) increases in $\mathbf{E \sigma}^{\mathbf{E}}$ activity. DNA sequence analysis of the region responsible for this phenotype indicated that the gene causing the increase in $\mathrm{E \sigma}^{\mathrm{E}}$ activity encodes an OMP, OmpX (J. Mecsas, R. Welch, J.W. Erickson, and C.A. Gross, in prep.). Because several other pISEs contained inserts that mapped to regions known to encode OMPs (Table 1), it seemed possible that overproducing a variety of OMPs could induce $\mathrm{E \sigma}^{\mathrm{E}}$ activity. To test this, multicopy plasmids encoding $\mathrm{OM}$ porins $\mathrm{OmpF}$ or OmpC, the OM protease OmpT, or OmpX were introduced into cells containing $\Phi \lambda[$ rpoHP3-lacZ]. Overpro-

A

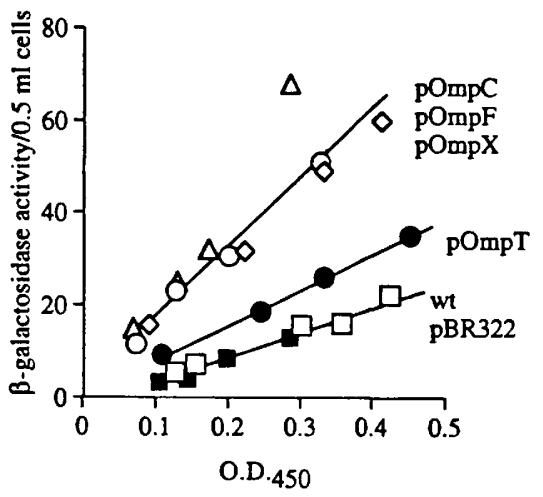

B

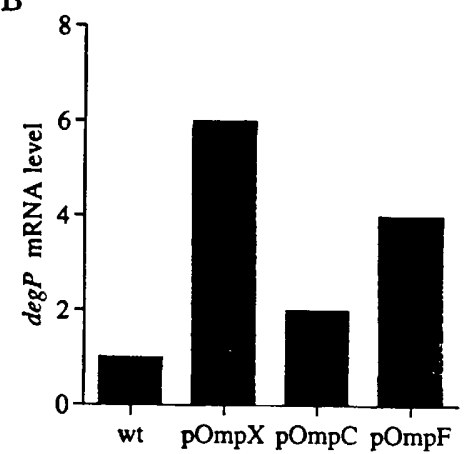

Figure 2. $(A) \mathrm{E}^{\mathrm{E}}$ activity in strains overexpressing OMPs from multicopy plasmids. $\beta$-Galactosidase activity in the parental strain (D) was compared with strains containing either pMY111

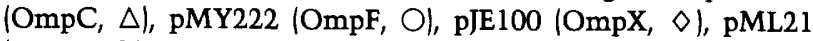
(OmpT, $\bullet$, or pBR322 (ロ). The data shown are representative of at least three experiments. The increase in $\mathrm{Tp} O \mathrm{HP} 3$ activity was 3- to 8-fold for strains overexpressing $\mathrm{OmpC}, \mathrm{OmpF}$, and $\mathrm{OmpX}$ and 1.4- to 2-fold for the strain overexpressing OmpT. The $r^{2}$ values (variance) for a linear fit of the points from each strain are all $>0.975$ for the data in this experiment. $(B) \operatorname{deg} P$ mRNA levels in MC1061Ф $\lambda[$ rpoHP3-lacZ] and isogenic strains overexpressing $\mathrm{OmpC}$, OmpF, or $\mathrm{OmpX}$ as assayed by $\mathrm{S} 1$ mapping. RNA was purified from cells grown at $30^{\circ} \mathrm{C}$ and harvested at an $\mathrm{OD}_{450}$ of $0.3-0.4$. Values were normalized to wild type and are averages of two to five measurements.

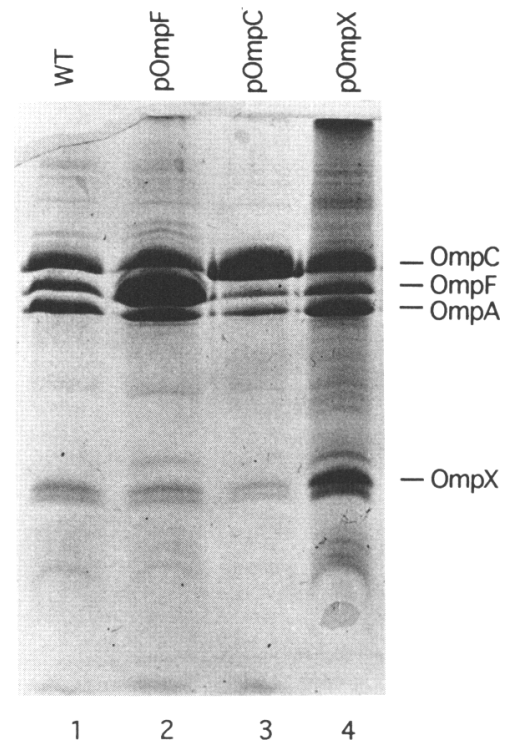

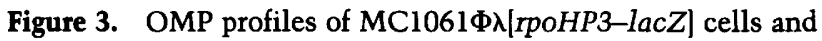
isogenic strains containing multicopy plasmids expressing OMPs. Equivalent amounts of cells were loaded in each lane. (Lane 1) Proteins from wild-type cells; (lane 2) pOmpF (pMY222); (lane 3) OmpC (pMY111); (lane 4) OmpX (pJE100).

duction of OmpC, OmpF, or OmpX caused an increase in E $\sigma^{\mathrm{E}}$ activity at both $r p o H P 3$ and the $\operatorname{deg} P$ promoters (Fig. $2 A, B)$. Furthermore, Figure 3 shows that these multicopy plasmids caused the expected increase of these proteins in the OM. Overproduction of OmpT, which was tested only at the rpoHP3 promoter, also caused a small but reproducible increase in $\mathrm{E \sigma}^{\mathrm{E}}$ activity (Fig. $2 \mathrm{~A}$ ), whereas pBR322 had no effect on E $\sigma^{\mathrm{E}}$ activity. This suggests that overexpression of a variety of OMPs induces $\mathrm{E \sigma}^{\mathrm{E}}$ activity and that PISE 13 and PISE48 were identified because they encode OmpT and OmpC, respectively.

\section{Underproduction of OMPs decreases E $\sigma^{E}$ activity}

In the screen designed to generate loss-of-function mutations that caused a decrease in $\mathrm{E}^{\mathrm{E}}$ activity, one locus was identified 16 independent times (Table 1). To determine the gene inactivated by the mini-Mu transposon, one transposon with flanking sequences was cloned. Restriction mapping indicated that the insertion was located in $\operatorname{ompR}$, a transcriptional activator of two major OM porins, OmpC and OmpF (Forst et al. 1988; Mizuno and Mizushima 1990). As expected, isolation of OMs from cells containing this insertion showed little OmpC and OmpF (data not shown). We considered two possible explanations for the decrease in $\mathrm{E \sigma}^{\mathrm{E}}$ activity of these

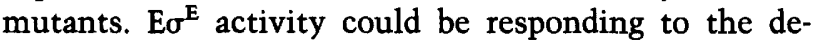
creased amount of OMPs present in the strain. Alternatively, $E \sigma^{\mathrm{E}}$ activity could depend on a pathway that is dependent on OmpR transcriptional activity. These two possibilities can be distinguished by overexpressing OmpX in a $\triangle o m p R$ strain. According to the first hypothesis, E $\sigma^{\mathrm{E}}$ activity will be high, whereas in the second, it 


\section{$\sigma^{\mathrm{E}}$ activity is modulated by OMP expression}

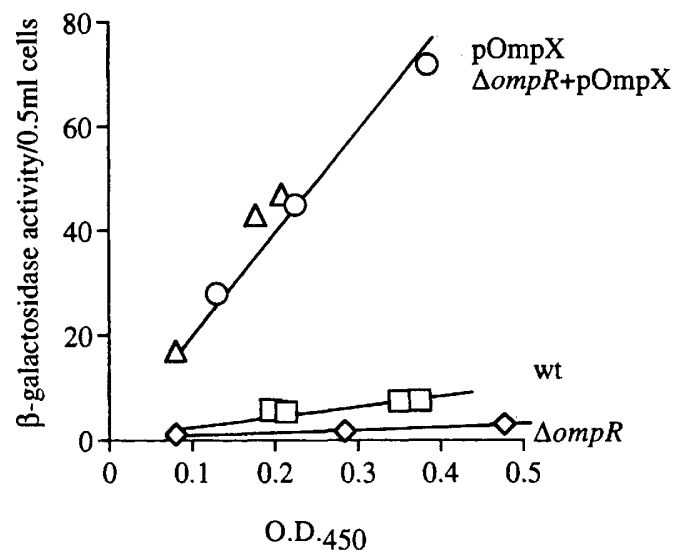

Figure 4. Overexpression of $\mathrm{OmpX}$ induces $\mathrm{E}^{\mathrm{E}}$ activity independent of ompR. $\beta$-Galactosidase activity in MC1061 $\Phi \lambda$ [rpoHP3-lacZ] (wt, $\square)$ was compared with isogenic strains containing $\Delta o m p R(\diamond)$, overproducing $\operatorname{OmpX}(\Delta)$, or overproducing OmpX in a $\Delta o m p R$ background (O). $\beta$-Galactosidase activity in $\Delta o m p R$ strain was three- to five-fold lower than the wild-type strain, and activity in the $\Delta o m p R+$ pJE100 strain was three- to six-fold higher than wild type in three experiments $\left(r^{2}>0.96\right)$.

will remain low. As shown in Figure $4, E \sigma^{\mathrm{E}}$ activity is induced by overproduction of $\mathrm{OmpX}$ in a $\triangle o m p R$ background. Thus, OmpR is not a transcriptional activator for $E \sigma^{\mathrm{E}}$. Instead, $E \sigma^{\mathrm{E}}$ activity appears to correlate with the amount of OMPs produced.

We asked whether decreasing the levels of other OMPs also affected $\mathrm{E}^{\mathrm{E}}$ activity. Lpp is the major OM lipoprotein in E. coli (Hirota et al. 1977). In an lpp5508 background Lpp is undetectable, and the E. coli OM is less stable and more sensitive to low amounts of detergents and chelating reagents. E ${ }^{\mathrm{E}}$ activity was decreased in an lpp5508 background (Fig. 5), supporting the idea that $\mathrm{E}^{\mathrm{E}}$ activity is reduced in cells with decreased OMP content.

\section{Cellular localization of signal-inducing $E \sigma^{E}$ activity by overexpression of OMPs}

To further understand how production of OMPs affects $\mathrm{E}^{\mathrm{E}}$ activity, the location of the signal generated by overproducing OMPs was determined. First, the location of the bulk of the overproduced OmpX was determined by fractionation of the cell into cytoplasmic, inner membrane, periplasm, and OM components. As expected, all detectable OmpX was in the OM (Fig. 6). This result, however, does not exclude the possibility that an undetected pool of OmpX was mislocalized or jammed in the secretion apparatus and, thus, caused the increase in $\mathrm{E}^{\mathrm{E}}$ activity. The following experiments were done to test these possibilities.

If OMP precursors in the cytoplasm generate a signal that induces $E \sigma^{\mathrm{E}}$ activity, then cells that accumulate OMP precursors in the cytoplasm should have a high level of $\mathrm{E \sigma}^{\mathrm{E}}$ activity. In fact, the converse was observed. In a $\sec B$ deletion strain, partially folded OMP precursors accumulate in the cytoplasm (Kumamoto 1991), but $\mathrm{E \sigma}^{\mathrm{E}}$ activity was reduced twofold (Fig. 7A). Thus, accumula-

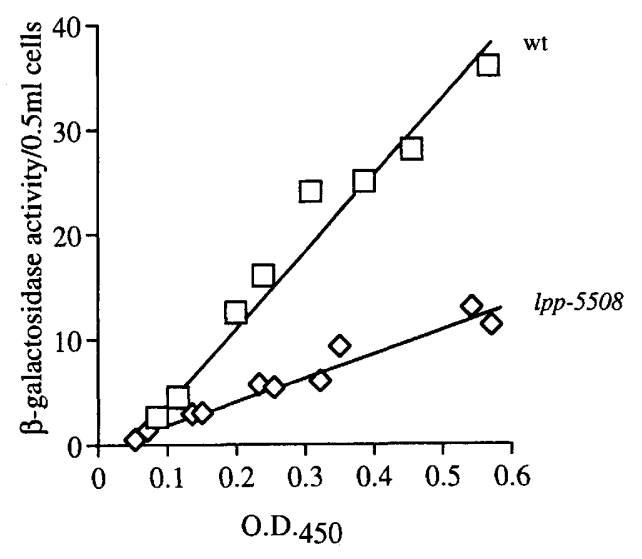

Figure 5. $\beta$-Galactosidase activity in MC1061Ф사poHP3lacZ] (wt, $\square$ ) compared with an isogenic strain containing lpp5508 $(\diamond)$. The difference in $\beta$-galactosidase activity ranged from three- to fivefold in two experiments $\left(r^{2}>0.95\right)$.

tion of OMP precursors in the cytoplasm does not induce E $\sigma^{\mathrm{E}}$ activity.

Overproduction of OMPs could titrate components of the inner membrane secretion apparatus, thereby generating a signal to increase $\sigma^{\mathrm{E}}$ activity. Because periplasmic proteins and OMPs share some cytoplasmic and inner membrane components of the secretion apparatus, overproduction of periplasmic proteins should also ti-

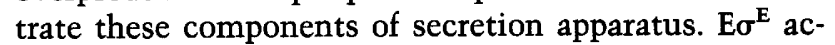
tivity, however, was unaffected when periplasmic proteins DegP or $\beta$-lactamase were overexpressed from high-copy-number plasmids (Fig. 7B). Western blot anal-

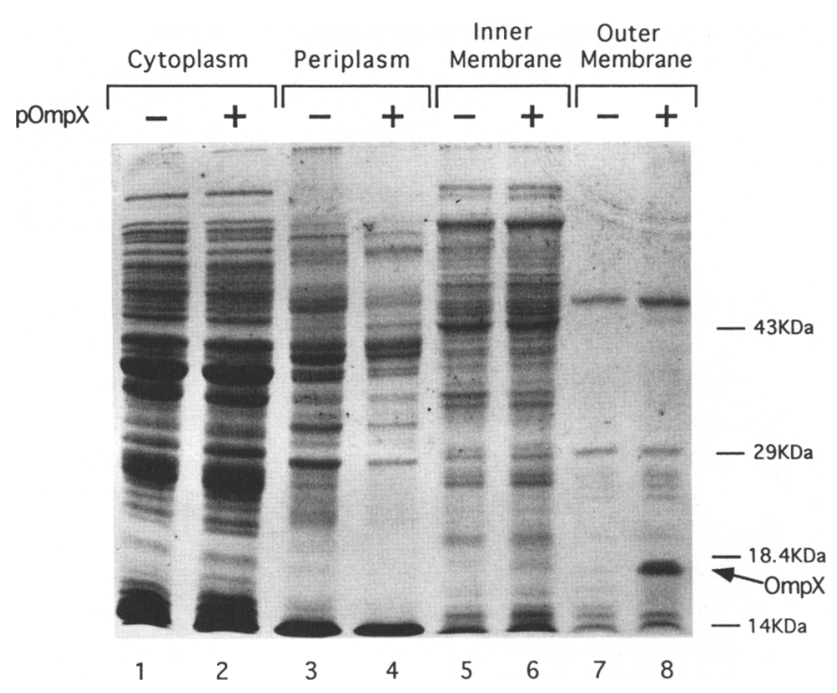

Figure 6. Protein profiles in different cell compartments in MC1061Ф $\lambda[$ rpoHP3-lacZ] wild-type cells and the otherwise isogenic strain overproducing OmpX (pIE100). Cells were fractionated as described in Materials and methods. Cytoplasmic (lanes 1,2), periplasmic (lanes 3,4), inner membrane (lanes 5,6), and OMPs (lanes 7,8 ), from wild type (lanes $1,3,5,7)$ and cells containing pJE100 (lanes $2,4,6,8$ ) were electrophoresed on a SDS-polyacrylamide gel. The OmpC and OmpF proteins were not resolved because this gel did not contain urea. 
A

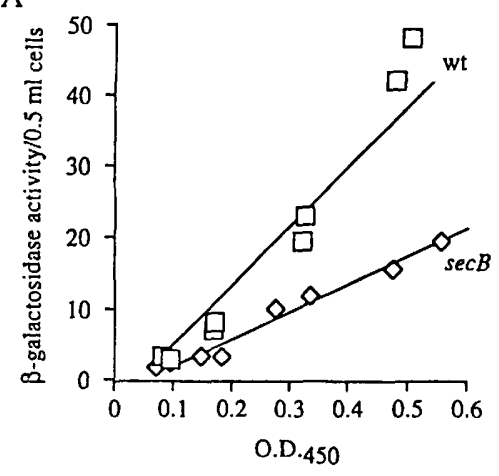

B

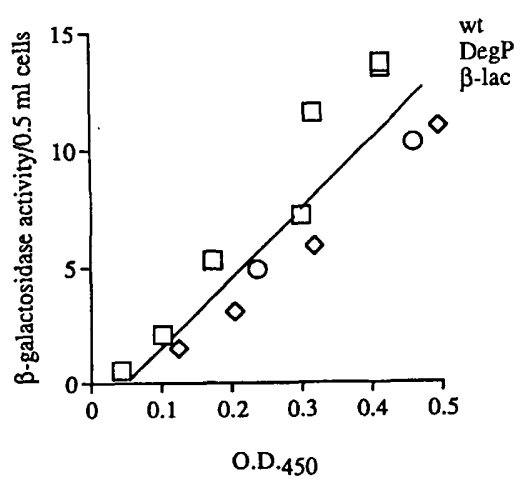

Figure 7. (A) $\beta$-Galactosidase activity in MC1061Ф入[rpoHP3-lacZ] (wt, $\square$ ) compared with an isogenic $\sec B(\diamond)$ strain. Cells were grown in M9 medium containing glycerol instead of glucose. The wild-type strain had about two-fold higher levels of $\beta$-galactosidase activity in media containing glycerol vs. glucose. $\beta$-Galactosidase activity was two- to three-fold higher in the wild-type strain compared with the $\sec B$ strains in two experiments $\left(r^{2}>0.96\right)$. (B) $\beta$-Galactosidase activity in $\mathrm{MCl061 \Phi} \lambda[$ [rpoHP3-lacZ] (wt, ㅁ) compared with isogenic strains overexpressing periplasmic proteins DegP $(\mathrm{pHtrA}, \mathrm{O}$ or $\beta$-lactamase (pUC19, $\diamond)$. $\beta$-Galactosidase activity in strains overproducing periplasmic proteins were within $35 \%$ of wild-type strain in two experiments $\left(r^{2}>0.95\right)$. $(C) \beta$-Galactosi-

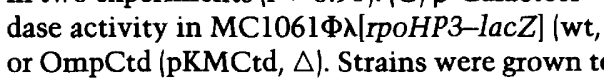

D

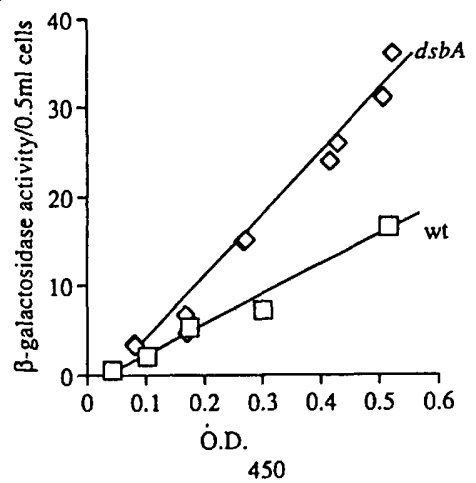

$\mathrm{C}$

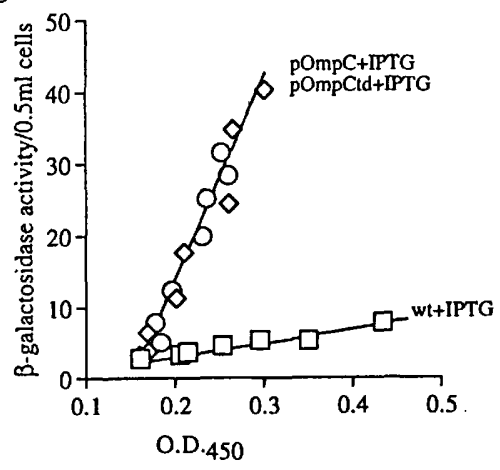

$\mathrm{E}$

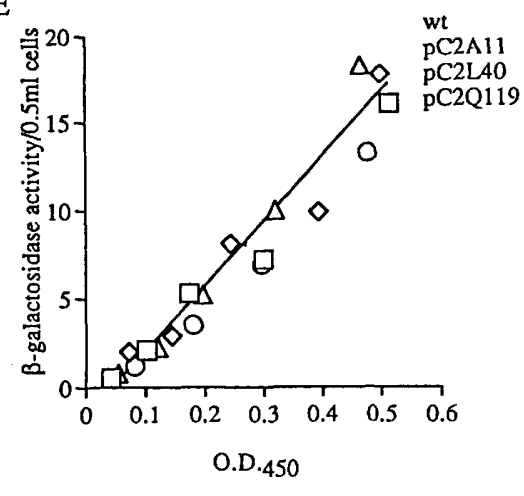
or Omptd (pKMCtd, $\triangle$ ). Strains were grown to an $\mathrm{OD}_{450}$ of 0.15 , and IPTG was added to a final concentration of $1 \mathrm{~mm}$. After addition of IPTG, the rate of $\beta$-galactosidase synthesis in strains overexpressing OmpC and OmpCtd increased 10- to 15-fold compared with the wild-type strain in three experiments. Growth of the pOmpCtd overproducing strain stopped $35 \mathrm{~min}$ after IPTG addition, whereas growth of the OmpC overproducing strain slowed immediately after IPTG addition $\left({ }^{2}>0.91\right)$. (D) $\beta$-Galactosidase activity in

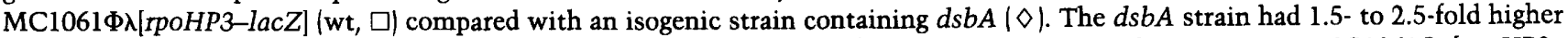
$\beta$-galactosidase activity than the wild-type strain in three experiments $\left(r^{2}>0.97\right)$. $(E) \beta$-Galactosidase activity in $M C 1061 \Phi \lambda[$ rpoHP3lacZ) (wt, $\square)$ compared with isogenic strains containing CycA-AP fusion proteins, pC2A11 $(\triangle), \mathrm{pC} 2 \mathrm{~L} 40(\mathrm{O})$, and pC2Q119 $(\diamond)$. $\beta$-Galactosidase activity in strains expressing CycA-AP fusion proteins were within $25 \%$ of the wild-type strain $\left(r^{2}>0.93\right)$.

ysis of DegP confirmed that expression from a multicopy plasmid increased the level of both the precursor and processed forms of DegP (data not shown). In addition, overproduction of periplasmic proteins MalE and alkaline phosphatase had no effect on E $\sigma^{E}$ activity (data not shown). These experiments suggest that overproduction of OMPs does not generate a signal for $\mathrm{E}^{\mathrm{E}}$ activity by titrating components of the secretion apparatus that are shared with periplasmic proteins. Furthermore, $E \sigma^{E}$ activity is not induced by increases in periplasmic proteins.

After transport through the inner membrane, the secretion pathways of periplasmic and OMPs diverge. Therefore, overproduced periplasmic proteins may not be in the same environment as overproduced OMPs. To specifically ask whether $\mathrm{E}^{\mathrm{E}}$ activity is induced by OMPs that are mislocalized in the periplasm or jammed in the secretion apparatus, $\mathrm{E \sigma}^{\mathrm{E}}$ activity was examined in a strain containing an OmpC variant that lacks 2 amino acids in the mature portion of the protein, OmpCtd (Catron and Schnaitman 1987). This variant is secreted through the inner membrane but is poorly incorporated in the $O M$ and inhibits incorporation of wild-type $\mathrm{OmpC}, \mathrm{OmpF}$, and OmpA into the OM. Induction of OmpCtd increases the activity of $\mathrm{E}^{\mathrm{E}} 10$ - to 15 -fold (Fig. $7 \mathrm{C})$. Thus, $\mathrm{E}^{\mathrm{E}}$ activity is induced under conditions that slow down the processing of OMPs after they have passed the inner membrane but before insertion in the OM.

Overproducing OMPs could cause them to aggregate or fold more slowly, resulting in accumulation of misfolded proteins. The $E$. coli $d s b A$ gene product was shown recently to facilitate disulfide bond formation of proteins in both the OM $(\mathrm{OmpA})$ and the periplasmic

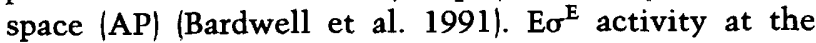
rpoHP3 promoter in a $\triangle d s b A$ background was induced about twofold (Fig. 7D). A similar effect on a $\operatorname{deg} P-$ lacZ fusion has been observed by P. Danese and T. Silhavy 
(pers. comm.). This suggests that $\mathrm{E}^{\mathrm{E}}$ activity may be induced by misfolded OMPs or periplasmic proteins.

Finally, to test whether misfolded periplasmic proteins induce $\mathrm{E}^{\mathrm{E}}$ activity, $\mathrm{E}^{\mathrm{E}}$ activity was tested in strains expressing protein fusions between portions of Rhodobacter sphaeroides CycA, a periplasmic $c$-type cytochrome (not found in E. coli), and alkaline phosphatase. These protein fusions are exported to the E. coli periplasm, and the CycA portion is then rapidly degraded. This indicates that these hybrid proteins do not fold properly (Brandner et al. 1991). Expression of these misfolded periplasmic proteins did not alter $\mathrm{E \sigma}^{\mathrm{E}}$ activity (Fig. 7E).

\section{Altering levels of the DegP protease has no effect on $E \sigma^{E}$ activity}

Results with the $\Delta d s b A$ strain suggested that E $\sigma^{\mathrm{E}}$ activity may be induced by misfolded OMPs. Although the substrates for the periplasmic DegP protease are unknown, these could include misfolded proteins or other molecules involved in signaling $E{ }^{\mathrm{E}}$ activity. Two experiments were designed to determine whether DegP levels, and presumably activity, influenced $\mathrm{E}^{\mathrm{E}}$ activity. A $\triangle \operatorname{deg} P$ strain should accumulate DegP substrates; however, E $\sigma^{\mathrm{E}}$ activity was unaffected (Fig. 8A). This indicates that either accumulation of DegP substrates does not induce $\mathrm{E}^{\mathrm{E}}$ activity or that other uncharacterized periplasmic proteases compensate for the lack of DegP.

Overproduced OMPs that induce $\mathrm{E \sigma}^{\mathrm{E}}$ activity could also be potential substrates for DegP. Thus, an increase in DegP in an OmpC overproducing strain might decrease $\mathrm{E} \sigma^{\mathrm{E}}$ activity. However, $\mathrm{E} \sigma^{\mathrm{E}}$ activity remained high in a strain with both DegP and OmpC encoded by multicopy plasmids (Fig. 8B). Thus, the signal generated by overproducing OmpC is not directly affected by the level of DegP protease.

\section{OMP levels do not affect expression from $E \sigma^{32}$ promoters}

Environmental stresses known to induce $\mathrm{E \sigma}^{\mathrm{E}}$ activity (temperature upshift and exposure to ethanol) also induce $\mathrm{E} \sigma^{32}$ activity. It was not clear, however, whether all conditions that increase $E \sigma^{\mathrm{E}}$ activity also increase $E \sigma^{32}$ activity. To test this, $E \sigma^{32}$ activity was assayed in a strain containing the $r p o D p H S$ promoter fused to $l a c Z$ on a prophage (Wild et al. 1992) under conditions that alter OMP levels. Neither the plasmids increasing OMP levels nor chromosomal mutations in ompR or $d s b A$ had any effect on $\mathrm{E}^{32}$ activity (Fig. 9A). As reported previously, a $\sec B$ mutation induced $\mathrm{E}^{32}$ activity fourfold (Wild et al. 1992a), presumably because a buildup of partially folded proteins in the cytoplasm activates the $\sigma^{32}$ regulon (Fig. 9B). Thus, changes in the levels of OMPs affects only the $E \sigma^{\mathrm{E}}$ regulon.

\section{Discussion}

We describe the results of experiments designed to identify positive regulators of E $\sigma^{\mathrm{E}}$ activity in E. coli. Initially,
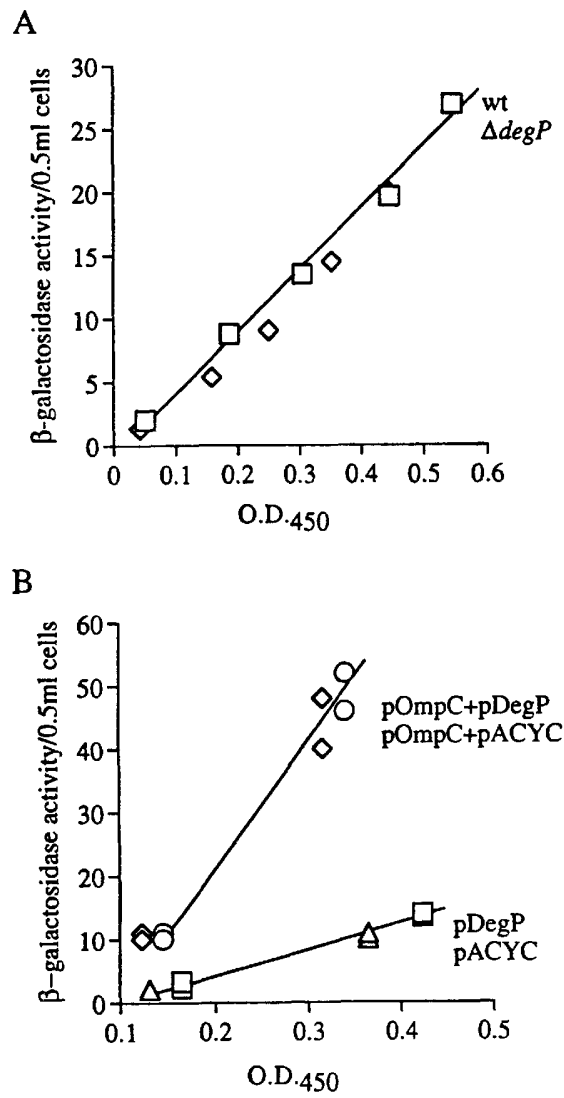

Figure 8. (A) $\beta$-Galactosidase activity in MC1061 $\Phi \lambda[$ rpoHP3lacZ] (wt, $\square$ ) compared with an isogenic strain containing $\operatorname{deg} P$ $(\diamond)$. $\beta$-Galactosidase activity of these two strains was within $10 \%$ in three experiments $\left(r^{2}>0.98\right)$. (B) $\beta$-Galactosidase activity in $\mathrm{MCl} 061 \Phi \lambda[\mathrm{rpoHP3}-\mathrm{lacZ}]$ isogenic strains overexpressing OmpC (pMY111, $\diamond), O m p C$, and DegP (pMY111 and pKS17, O) compared with cells overexpressing $\operatorname{DegP}(\mathrm{pSK} 17, \triangle)$, or wildtype cells (pACYC184, ㅁ). $\beta$-Galactosidase activity between cells overproducing OmpC or OmpC and DegP was within $10 \%$; these cells had four- to sixfold more $\beta$-galactosidase activity than cells overproducing DegP alone or wild-type cells $\left(r^{2}>0.97\right)$.

two genetic strategies were used to allow identification of a broad range of regulators because each approach has limitations. The screen for loss-of-function mutants fails to identify regulators that are essential, are not required for growth at high temperature, or have redundant functions. The multicopy selection fails to identify genes that cannot be cloned on multicopy vectors or gene products with activity that does not increase with increasing gene dosage. The initial results from these complementary approaches indicate that $\mathrm{E}^{\mathrm{E}}$ activity changes when the level of OMPs is altered. On the basis of these observations, we showed that increasing the amount of $\mathrm{OmpX}, \mathrm{OmpT}, \mathrm{OmpF}$, or OmpC increases E $\sigma^{\mathrm{E}}$ activity. Furthermore, mutations that increase the amount of misfolded OMPs or reduce the efficiency of OMP incorporation into the $\mathrm{OM}$ induce $\mathrm{E \sigma}^{\mathrm{E}}$ activity. Decreasing specific OMPs, Lpp or OmpF and OmpC, or decreasing 
A

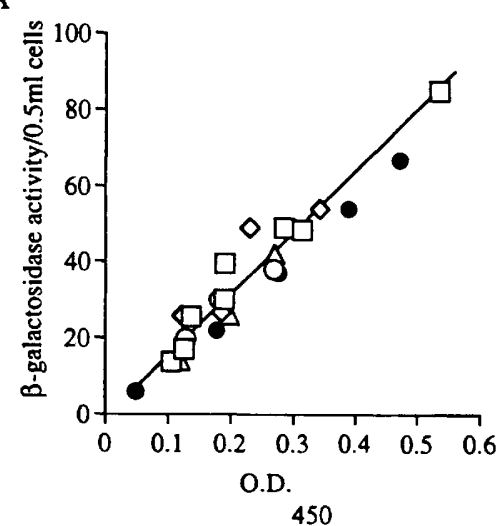

B

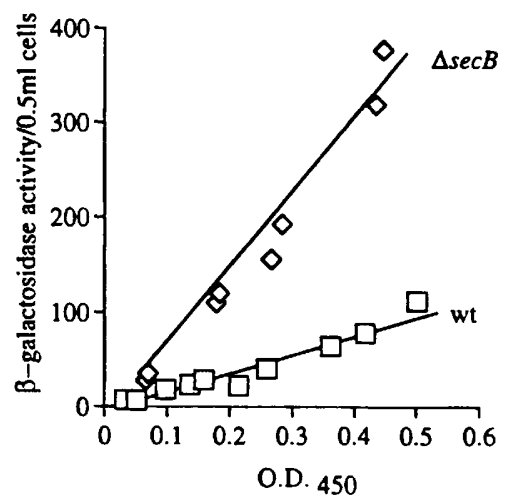

Figure 9. (A) $\beta$-Galactosidase activity in MC1061 $\Phi \lambda[$ rpoDpHSlacZ] (wt, $\square$ ) compared with isogenic strains overexpressing OmpC (pMY111, $\diamond)$ or OmpX(pJE100, $\Delta)$, or with insertions in $o m p R(O)$ or $d s b A$ (O). Differences in $\beta$-galactosidase activity among these strains were within $20 \%\left(r^{2}>0.95\right)$. (B) $\beta$-Galactosi-

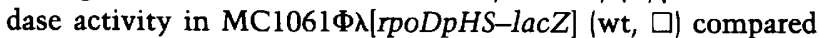
with an isogenic strain containing $\sec B(\diamond)$. The $\sec B$ strain had four-fold higher $\beta$-galactosidase activity than the wild-type strain in two experiments $\left(r^{2}>0.94\right)$.

OMP levels indirectly by SecB limitation reduces $E \sigma^{E}$ activity. Thus, one signal that modulates $\mathrm{E}^{\mathrm{E}}$ activity is linked to production of OMPs.

\section{Where in the cell do overproducing OMPs generate a signal?}

Although all of the detectable overproduced wild-type OMPs are in the OM, the signal need not originate there. OMPs transverse several cellular compartments before insertion into the OM (for review, see Pugsley 1993). They are synthesized as precursor proteins containing an amino-terminal signal sequence, maintained in a translocation-competent form by interaction with cellular chaperones such as $\mathrm{SecB}$, targeted to the membrane by interaction with SecA, transported through the cytoplasmic membrane by the SecY/E translocase, and cleaved by a signal peptidase as they exit the secretion machinery. These steps are common to both periplasmic proteins and OMPs. OMPs are then localized to the OM either through a periplasmic intermediate (Sen and Nikaido 1990) or by direct transfer to the OM at attachment sites (Bayer et al. 1982). This latter process is not well understood. The signal generated by gross changes in production of OMPs could be located in any of these compartments.

Our results suggest that the signal controlling $\mathrm{E \sigma}^{\mathrm{E}}$ activity is not generated during the early steps in the translocation of OMPs. A $\Delta s e c B$ strain accumulates precursors of periplasmic proteins and OMPs in the cytoplasm (Kumamoto 1991) but does not induce E $\sigma^{\mathrm{E}}$ activity. This suggests that the signal generated by overproducing OMPs does not result from accumulation of cytoplasmic precursor proteins or from $\sec B$ limitation. Overexpression of proteins normally located in the periplasm also does not induce $E \sigma^{\mathrm{E}}$ activity. Because periplasmic proteins use the same translocase as OMPs (Pugsley 1993), it is unlikely that overproduced OMPs generate a signal by titrating the translocase. Finally, expression of foreign proteins localized to the periplasm or accumulation of DegP substrates does not alter $\mathrm{E \sigma}^{\mathrm{E}}$ activity. This suggests that a signal is not generated by aberrant periplasmic proteins. However, overexpressing OmpCtd (Catron and Schnaitman 1987), an aberrant OMP that is translocated but poorly incorporated into the OM, does induce $\mathrm{E \sigma}^{\mathrm{E}}$. On the basis of these observations, we propose that the signal for $\mathbf{E \sigma}^{\mathrm{E}}$ originates after the translocation pathways of OMP and periplasmic proteins diverge. The signal could be generated as the OMP exits the cytoplasmic membrane, in the periplasm, or in the OM. The extracellular location of the signal necessitates that a signaltransduction pathway exists to propagate the signal back through the inner membrane to influence the activity of $\mathrm{E} \sigma^{\mathrm{E}}$ in the cytoplasm.

\section{What is the signal?}

Although we have not quantitatively measured OMPs, it is known that the total amount of OMPs in the membrane can change by as much as $30 \%$ (Diedrich and Fralick 1982). Our data suggest that the total amount of OMPs produced directly correlates with $\sigma^{\mathrm{E}}$ activity. We consider two different ways in which varying the amount of OMP production could generate a signal that modulates $\mathrm{E \sigma}^{\mathrm{E}}$ activity. First, changing the amount of OMP production could change the composition of the $\mathrm{OM}$. Alternatively, if we assume that a change in OMP levels reflects a change in their rate of synthesis, a change in the flow rate of OMPs through the system that targets OMPs to the OM could generate a signal.

In the first scenario, the composition of the OM could vary by changing either the absolute amount or the relative ratios of individual OMPs. Altering the absolute amount of OMPs could change the ratio of protein to either lipid or peptidoglycan and generate a signal, possibly by changing the structural integrity or fluidity of the cell envelope. However, to the extent that we have assayed this, $\mathrm{E}^{\mathrm{E}}$ is not sensing structural integrity of the cell envelope. Both the lpp5508 mutation (Hirota et al. 1977) and overproduction of OmpX, OmpC, and OmpF 
(data not shown) result in increased sensitivity to detergents and chelating reagents, yet these alterations have opposite effects on $\mathrm{E \sigma}^{\mathrm{E}}$ activity. Alternatively, the signal could be generated by a change in relative ratios of individual OMPs. Overproducing some OMPs leads to underrepresentation of other OMPs in the OM /Click et al. 1988). If one OMP negatively regulates E ${ }^{\mathrm{E}}$ activity, then overproducing other OMPs could decrease its level whereas underproducing other OMPs could increase its level. Although such a protein may exist, we were unable to identify one protein that varied consistently with $E \sigma^{E}$ activity (data not shown). For instance, OmpA increases in the $\Delta o m p R$ strain and decreases in a $\Delta \sec B$ strain, yet both strains had decreased E $\sigma^{\mathrm{E}}$ activity.

A second way of generating the signal modulating $\mathrm{E \sigma}^{\mathrm{E}}$ activity can be derived by considering the pathway that targets OMPs to the OM (Bayer et al. 1982; Sen and Nikaido 1990; Pugsley 1993). OMPs must be sorted from periplasmic proteins, transported to the $O M$, and folded properly. Although the specific components of this pathway are poorly understood, the pathway is likely to involve chaperones to maintain OMPs in appropriate protein conformations, molecules that target OMPs to the $\mathrm{OM}$, and possibly molecules that insert OMPs in the membrane. A change in the flow rate of OMPs through this pathway could generate the signal modulating $\mathbf{E}^{\mathbf{E}}$ activity. For example, a chaperone involved in the transport of proteins to the OM could also interact with the signal-transduction pathway modulating $\mathrm{E \sigma}^{\mathrm{E}}$ activity. Overproduction of OMPs could titrate or alter the activity of this chaperone and signal for an increase in $\mathrm{E \sigma}^{\mathrm{E}}$ activity, whereas underproduction of OMPs would have the converse effect.

\section{Why are both the $E \sigma^{E}$ and $E \sigma^{32}$ regulons induced by heat?}

We believe that the answer to this question arises from a consideration of signals that uniquely induce each regulon. Conditions that increase the amounts of unfolded, partially folded, or misfolded proteins in the cytoplasm induce $\mathrm{E}^{32}$ but not $\mathrm{E} \sigma^{\mathrm{E}}$. Conversely, conditions that increase OMPs in compartments outside the cytoplasm induce $E \sigma^{\mathrm{E}}$ but not $\mathrm{E}^{32}$. Two distinct regulons may exist to allow cells to respond to processes or signals that are unique to each compartment. Thus, just as the products of the $E \sigma^{32}$ regulon are involved in responding to environmental stimuli affecting the processing of cytoplasmic proteins, the products of the E ${ }^{\mathrm{E}}$ regulon could be involved in responding to environmental stimuli affecting the OM or the processing of OMPs. Although $\mathbf{E \sigma}^{\mathbf{E}}$ transcribes $r p o H$, transcription from the $\mathrm{E \sigma}^{\mathrm{E}}$ promoter accounts for $<5 \%$ of total transcription of $r p o H$ at $30^{\circ} \mathrm{C}$ (Erickson et al. 1987) Furthermore, E ${ }^{32}$ activity is posttranscriptionally regulated (Straus et al. 1987, 1989). Thus, increases in $\mathrm{E}^{\mathrm{E}}$ activity do not necessarily increase $\mathbf{E} \boldsymbol{\sigma}^{32}$ activity at moderate temperatures.

In Gram-negative bacteria, the composition of the OM changes in response to many environmental conditions including temperature, osmolarity, dessication, starva- tion, and growth in other hosts. The products of the $\mathrm{E \sigma}^{\mathrm{E}}$ regulon could be involved in responding to environmental changes that affect processing of OMPs. In addition to the periplasmic location of DegP, circumstantial evidence exists for an extracytoplasmic role of the products of the $E \sigma^{\mathrm{E}}$ regulons. $\mathrm{E}{ }^{\mathrm{E}}$ recognizes promoters for two secreted hydrolytic enzymes (Erickson and Gross 1989), $\operatorname{dag} A$ (Buttner et al. 1988) and phlA1 (Givskov et al. 1988) from Streptomyces coelicolor and Serratia liquefaciens, respectively. If $\sigma^{\mathrm{E}}$ homologs in $S$. coelicolor and $S$. liquefaciens are involved in transcription of these genes, the $\mathrm{E \sigma}^{\mathrm{E}}$ regulon may consist of extracytoplasmic proteins that are involved in altering the protein composition of the OM, periplasm, or extracellular space. The $\operatorname{deg} P$ homolog in Salmonella (htrA) plays a role in virulence and appears to have an $E \sigma^{E}$ promoter (Johnson et al. 1991). This suggests the exciting possibility that E $\sigma^{\mathrm{E}}$ activity may be induced during growth in and colonization of animals.

An appealing, but speculative, idea is that these two $\sigma$-factors may have complementary but distinct functions; both may be involved in protein processing - the $\mathrm{E} \sigma^{32}$ regulon in the cytoplasm and the E $\sigma^{\mathrm{E}}$ regulon in the extracytoplasmic compartments. It is clear that $E \sigma^{32}$ is induced by misfolded proteins in the cytoplasm; our data indicate that $E \sigma^{\mathrm{E}}$ may be induced by misfolded OMPs in other compartments. We and others (P. Danese and T. Silhavy, pers. comm.) have shown that the $\triangle d s b A$ mutation, which creates misfolded or partially folded proteins in the periplasm and $\mathrm{OM}$, induces $E \sigma^{\mathrm{E}}$. A second $\mathrm{E \sigma}^{\mathrm{E}}$ inducer, OmpCtd, may cause accumulation of misfolded or improperly localized OMPs in an extracellular compartment. Finally, we have argued that overproducing OMPs may induce $\mathrm{E \sigma}^{\mathrm{E}}$ activity by saturating the pathway that inserts OMPs into the OM, thus increasing the pool of incompletely folded proteins in the extracytoplasmic compartments of the cell.

That two E. coli $\sigma$-factors may be induced by similar molecular cues in different cellular compartments is reminiscent of the situation in eukaryotic cells where unfolded or damaged proteins in different compartments or organelles induce chaperones by parallel but independent mechanisms. Unfolded proteins in the cytoplasm induce the heat shock response, possibly by titrating out Hsp70 (Craig and Gross 1991). Unfolded proteins in the endoplasmic reticulum induce a set of proteins residing in this compartment by interacting with BIP, an Hsp70 family member found exclusively in the endoplasmic reticulum (Kozutsumi et al. 1988; Mori et al. 1992). Future experiments addressing the exact nature of the signal that modulates E $\sigma^{\mathrm{E}}$ activity and how the signal is transduced back to the cytoplasm should provide biologists with insights into how different cell compartments respond to similar environmental or physiological cues.

\section{Materials and methods}

\section{Media and strains}

All media were prepared as described (Miller 1972). Liquid cultures were grown in M9 glucose supplemented with vitamins 
and all 20 common amino acids, except for experiments involving the secB::kan allele. In those experiments, both wild-type

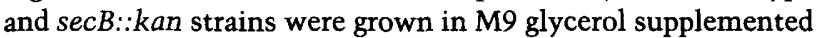
with vitamins and all 20 common amino acids. Solid media used were MacConkey lactose, MacConkey galactose, LB, and M9 glycerol supplemented with amino acids and vitamins. Drug concentrations were $50 \mu \mathrm{g} / \mathrm{ml}$ of ampicillin, $30 \mu \mathrm{g} / \mathrm{ml}$ of kanamycin (Kan), $10 \mu \mathrm{g} / \mathrm{ml}$ of tetracycline (Tet), and 20-75 $\mu \mathrm{g}$ / $\mathrm{ml}$ of chloramphenicol (Cam).

CAG16028 $\Delta$ (araCOIBA, leu)7696, araD139, galK, galU, $h s d R, \Delta($ lac $) X 74$, recA56, $r p s L$, a derivative of $M C 1061$ was used for making the RNA for the S1 assays. Most $\beta$-galactosidase assays were done in CAG16028 lysogenized with either the $\Phi \lambda[$ rpoHP3-lacZ] resulting in CAG16037 or $\Phi \lambda[$ [rpoDpHS-lacZ] resulting in CAG16074 (Wild et al. 1992). CAG16038 was a derivative of $\mathrm{C} 600$ galK containing pJEK61 (Erickson and Gross 1989|. CAG16040 was a derivative of C600 galK containing plasmid with PgalK driving galK expression. For identification and initial characterization of the pISE plasmids, M8820 MuCts (Groisman and Casadaban 1986) was lysogenized with $\lambda \Phi[$ rpoHP3-lacZ] generating CAGl6045 and transformed with P3CAT generating CAG16052 to select for increased $\mathrm{E}^{\mathrm{E}}$ activity. The secB::kan allele (Kumamoto and Beckwith 1985) was introduced into CAG16037 and CAG16074 using P1 transduction. To facilitate manipulation of the lpp5508 allele (Hirota et al. 1977), a Tn10tet $(z d h-925:: \operatorname{Tn} 10)$ was linked to this mutation (Singer et al. 1989). The linked Tet $^{\mathrm{R}}$ was then transferred to CAG16037 or CAG16074 by P1 transduction. The presence of the lpp5508 allele was determined by increased sensitivity to SDS and EDTA (Hirota et al. 1977). The $d s b A::$ kan (Bardwell et al. 1991) and $\operatorname{deg} P::$ kan (Strauch and Beckwith 1988) alleles were transferred to CAG16037 and CAGl6074 by P1 transduction.

\section{Plasmids and phage}

The following plasmids were used to express the proteins indicated in parentheses and have been described previously: pKS17 (DegP) (Strauch and Beckwith 1988), pMY111 (OmpC) (Mizuno et al. 1983), pMY222 (OmpF) (Ramakrishnan et al. 1985), pML21 (OmpT) (Grodberg et al. 1988), pC2A11, pC2L40, and pC2Q119 (CycA-AP fusions) (Brandner et al. 1991), pGMCl ( $\left.\mathrm{P}_{\mathrm{tac}}-\mathrm{OmpC}\right)$ and pKMCtd ( $\mathrm{P}_{\text {tac }}-$ OmpCtd) (Catron and Schnaitman 1987), and pHtrA (DegP) (Lipinska et al. 1988). To make pP3CAT, which was used in the multicopy selection, a 37-bp fragment of the P3 promoter of $r p o H$ (Erickson and Gross 1989) was cloned into pKK232-8 (Pharmacia), resulting in pJM14. A 2.4-kb HgiAI fragment of pJM14 was cloned into the $2.8-\mathrm{kb} B s a \mathrm{Al}$ fragment of pACYC184 resulting in pP3CAT. pJEK61 (Erickson and Gross 1989) was used in the screen for loss-of-function mutants. The pISE plasmids and the parental pEG5005 plasmids were generated as described (Groisman and Casadaban 1986). pJE100 is described (J. Mecsas, R. Welch, J. Erickson, and C.A. Gross, in prep.). The $\Phi \lambda[$ rpoHP3-lacZ] was constructed by cloning the SalI-EcoRI fragment of pJEK61 into pRS415 and crossing the resulting plasmid with $\lambda$ RS45 as described (Simons et al. 1987). $\Phi \lambda[r p o D p H S-l a c Z]$ was described (Wild et al. 1992b).

\section{Genetic selections}

To select for genes that increase $\mathrm{E}^{\mathrm{E}}$ activity when overexpressed, a multicopy library was made using a mini-Mu system (Groisman and Casadaban 1986). CAG16052 was infected with a high-titer lysate containing this library, and appropriate dilutions were plated on LB plates supplemented with Kan and 20$75 \mu \mathrm{g} / \mathrm{ml}$ of Cam. Approximately $7000 \mathrm{Kan}^{\mathrm{R}}$ colonies were plated on a total of four plates at each Cam concentration. Unexpectedly, the presence of the pEG5005 vector sequences caused an increase in the resistance of CAG16052 to Cam; thus, the efficiency of plating was higher than expected. Cells that grew faster than the CAG16052 + pEG5005 strain were picked: Eighteen colonies were picked on $20 \mu \mathrm{g} / \mathrm{ml} ; 14$ colonies were picked on $40 \mu \mathrm{g} / \mathrm{ml}$; and 8 colonies were picked on $50 \mu \mathrm{g} / \mathrm{ml}$ and $75 \mu \mathrm{g} / \mathrm{ml}$. Colonies were purified twice; plasmid DNA was isolated and used to transform CAG16045 to show that the increase in $\mathrm{E}^{\mathrm{E}}$ activity was linked to the plasmid. Of the original 48 colonies picked, 22 resulted in an increase in $\mathrm{E}^{\mathrm{E}}$ activity at both the rpoHP3 and $\operatorname{deg} P$ promoters and were mapped to the Kohara phage.

To generate cells with insertions in positive regulators of genes for $\mathrm{E}^{\mathrm{E}}$ activity, mini-Mu transposon mutagenesis was performed as described (Castilho et al. 1984) using the $\mathrm{Mu}$ dII1734 transposon. CAG16038 was infected with a mini-Mu lysate, plated on MacConkey plates containing galactose and Kan, and grown at either $20^{\circ} \mathrm{C}$ or $30^{\circ} \mathrm{C}$. White $\mathrm{Kan}^{\mathrm{R}}$ colonies were patched onto MacConkey-galactose plates and grown at $30^{\circ} \mathrm{C}$ and $44^{\circ} \mathrm{C}$. Mutants that grew poorly at $44^{\circ} \mathrm{C}$ were taken from the $30^{\circ} \mathrm{C}$ plate, colony purified, and tested for $\mathrm{Mu}^{\mathrm{S}}$. To test that the insertion specifically reduced $\mathrm{E \sigma}^{\mathrm{E}}$ activity, $\mathrm{Pl}$ was grown on the white, temperature-sensitive, $\mathrm{Mu}^{\mathrm{s}}$ cells and the lysate was used to transduce CAG16038 or CAG16040 to $\mathrm{Kan}^{\mathrm{R}}$. Only $\mathrm{Kan}^{\mathrm{R}}$ insertions that conferred the galK- phenotype in CAG16038 (which carries galK under $\mathrm{E \sigma}^{\mathrm{E}}$ control) but not CAGl6040 (which carries galK under $\mathrm{E \sigma}^{70}$ control) were studied further. Approximately $22,500 \mathrm{Kan}^{\mathrm{R}}$ cells were screened $(8000$ at $20^{\circ} \mathrm{C}$ and 14,500 at $30^{\circ} \mathrm{C}$ ); $3 \%$ of the $\operatorname{Kan}^{\mathrm{R}}$ cells were white; $1 \%$ of the white cells were temperature sensitive; $50 \%$ of the temperature sensitive cells were $\mathrm{Mu}^{\mathrm{s}}$; 16 colonies had mini$\mathrm{Mu}$ insertions that gave rise to white, $\operatorname{Kan}^{\mathrm{R}}$ colonies when transduced into CAG16038 and red when transduced into CAG16040. The location of one insertion was mapped genetically using high frequency recombination F-factors (Hfrs) and linked Tn10tet (Singer et al. 1989). All of the other insertions were linked to the same Tn10. To identify the gene into which the mini-Mu inserted, chromosomal DNA from one insertion strain was isolated and digested with either HindIII or BamHI. These enzymes do not cleave the $\mathrm{kan}^{R}$ gene allowing for cloning of adjacent chromosomal DNA. Digested DNA was ligated to pUC19 with either HindIII or BamHI and transformed into DH5 $\alpha$. Plasmids from $\mathrm{Kan}^{\mathrm{R}}$ colonies were analyzed with various restriction enzymes and compared with the restriction map of the E. coli chromosome between 74 and $76 \mathrm{~min}$ using the GeneScape program (Bouffard et al. 1992). The restriction pattern matched that of the ompB locus and showed that the $\mathrm{Mu}$ $d \Pi 1734$ transposon had inserted $100 \mathrm{bp}$ after the translational start site of the $O m p R$ gene.

\section{Mapping pISE inserts and location of dse}

A nylon membrane containing a subset of 466 phage from the collection of Kohara (Kohara et al. 1987) was obtained from Takara Biochemical. The plasmids were nick-translated, and hybridization, washing, and stripping of the membrane were done as recommended by Takara Biochemical.

\section{$\beta$-Galactosidase assays}

$\beta$-Galactosidase levels were measured as described (Miller 1972). Overnight cultures were diluted $1 / 1000$ or to an $\mathrm{OD}_{450}$ of 0.004 in the appropriate medium and grown at $30^{\circ} \mathrm{C}$. Cells $(0.5 \mathrm{ml})$ were lysed with chloroform and one drop of $0.1 \%$ SDS. For line graphs, $\beta$-galactosidase activity was calculated by 
$\sigma^{E}$ activity is modulated by OMP expression

([ $\left.\mathrm{A}_{42 \mathrm{O} \text { (final) }}-\mathrm{A}_{420 \text { (initial) }}\right] /(\mathrm{min}$ of reaction with $\mathrm{ONPG}) \times 1000$ and plotted as a function of $\mathrm{OD}_{450}$ of the cells. Values in Figure 1 were divided by the $A_{450}$ and normalized to the wild-type case. Although the level of $\beta$-galactosidase activity varied as much as threefold from day to day, all strains were affected equally; thus, the relative values remained constant. This unusually large variation could be the result of subtle changes in culture conditions that influence $\mathrm{E \sigma}^{\mathrm{E}}$ activity.

\section{S1 mapping}

pHtrA was used as the source of probe for the S1 mapping experiments as described (Lipinska et al. 1988). RNA harvesting (Barry et al. 1980) and S1 mapping (Maniatis et al. 1982) were performed as described. A constant amount of RNA was used in each assay. To control for losses during manipulations in the $S 1$ assay, we used a second probe, pRL385, to a portion of the $r p o B$ gene (Landick et al. 1990). Samples were electrophoresed on a $5 \%$ polyacrylamide- $50 \%$ urea gel, and the gel was dried. To quantitate transcription from the $\operatorname{deg} P$ promoter, radioactivity in the $\operatorname{deg} P$ and $r p o B$ transcripts was counted using an Ambis scanner. Changes in transcription from the $\operatorname{deg} P$ promoter were calculated by $\left[\mathrm{cpm} \operatorname{deg} P_{(\text {mutant })} / \mathrm{cpm} \quad r p o B_{(\text {mutant })}\right] /[\mathrm{cpm}$ $\operatorname{deg} P_{\text {(wild type) }} / \mathrm{cpm} r p o B_{\text {(wild type) }}$.

\section{Fractionation of cellular components}

Protein composition of the inner membrane and OM was analyzed using their differential solubility in sarcosyl. Ten milliliters of cells growing in $\mathrm{LB}$ medium were harvested at an $\mathrm{OD}_{600}$ of 1 . Cell pellets were resuspended in $500 \mu \mathrm{l}$ of $100 \mathrm{~mm}$ Tris$\mathrm{HCl}\langle\mathrm{pH} 8.0\rangle, 10 \mathrm{~mm}$ EDTA and transferred into an Eppendorf tube. Cell walls were digested with lysozyme $(100 \mu \mathrm{g} / \mathrm{ml})$ on ice for $10 \mathrm{~min} . \mathrm{MgCl}_{2}(10 \mathrm{~mm})$ and DNase $\mathrm{I}(50 \mu \mathrm{g} / \mathrm{ml})$ were added, and the spheroplasts were lysed by three freeze-thaw cycles. The lysate was centrifuged for $10 \mathrm{~min}$ at $15,000 \mathrm{~g}$. The supernatant (cytoplasmic and periplasmic fractions) was removed, and the pellet (crude membrane fraction) was washed with $500 \mu l$ of $20 \mathrm{mM} \mathrm{NaPO}{ }_{4}$ (pH 7.0). The inner membrane and $\mathrm{OM}$ were resolved by solubilizing specifically the inner membrane with $100 \mu \mathrm{l}$ of $0.5 \%$ sarcosyl in $20 \mathrm{~mm} \mathrm{NaPO}_{4}$ for $30 \mathrm{~min}$ at room temperature. The insoluble OMs were pelleted by centrifugation for $10 \mathrm{~min}$ at $15,000 \mathrm{~g}$, washed with $100 \mu \mathrm{l}$ of sarcosyl, centrifuged again, resuspended in SDS sample buffer, and boiled for $5 \mathrm{~min}$. Proteins were analyzed on a $12 \%$ polyacrylamideSDS gel. For Figure 3, the gel also contained 50\% urea to resolve OmpC and OmpF. When periplasm and cytoplasm were separated, the cell wall was digested in $20 \%$ sucrose to prevent lysis of the spheroplasts (Brissette and Russel 1990).

\section{Acknowledgments}

We thank Jori Vetzner for excellent technical assistance. We thank J. Bardwell, J. Beckwith, J. Brandner, M. Inouye, J. Klena, M. Lundrigan, S. Raina, G. Ramakrishnan, C. Schnaitman, T. Silhavy, and K. Strauch for providing plasmids and/or strains. We thank J. Bardwell, P. Danese, and T. Silhavy for discussing results before publication. We thank E. Craig, L. Heisler, A. Kamath-Loeb, and P. Rossmeissl for valuable discussions and critical reading of the manuscript. This research was supported by National Institutes of Health (NIH) grant GM36278-06 to C.A. Gross, and NIH grant GM37509 to T.J. Donohue.

The publication costs of this article were defrayed in part by payment of page charges. This article must therefore be hereby marked "advertisement" in accordance with 18 USC section 1734 solely to indicate this fact.

\section{References}

Alfano, C. and R. McMacken. 1989. Heat shock protein-mediated disassembly of nucleoprotein structures is required for the initiation of bacteriophage $\lambda$ DNA replication. $J$. Biol. Chem. 264: 10709-10718.

Bardwell, J.C.A., K. McGovern, and J. Beckwell. 1991. Identification of a protein required for disulfide bond formation in vivo. Cell 67: 581-589.

Barry, G., C. Squires, and C.L. Squires. 1980. Attenuation and process of RNA from the rplJL-rpoBC transcription unit of RNA polymerase. Proc. Natl. Acad. Sci. 77: 3331-3335.

Bayer, M.H., G.P. Costello, and M.E. Bayer. 1982. Isolation and partial characterization of membrane vesicles carrying markers of the membrane adhesion sites. J. Bacteriol. 149: 758-767.

Bouffard, G., J. Ostell, and K.E. Rudd. 1992. GeneScape: A relational data base of Escherichia coli genomic map data for MacIntosh computers. Comput. Applic. Biosci. 8: 563-567.

Brandner, J.P., E.V. Stabb, R. Temme, and T.J. Donohue. 1991. Regions of Rhodobacter sphaeroides cytochrome c2 required for export, heme attachment and function. J. Bacteriol. 173: 3958-3965.

Brissette, J.L. and M. Russel. 1990. Secretion and membrane integration of a filamentous phage-encoded morphogenetic protein. I. Mol. Biol. 211: 565-580.

Burgess, R.R., A.A. Travers, J.J. Dunn, and E.K.F. Bautz. 1969. Factor stimulating transcription by RNA polymerase. $\mathrm{Na}$ ture 221: 43-46.

Buttner, M.J., A.M. Smith, and M.J. Bibb. 1988. At least three different RNA polymerase holoenzymes direct transcription of the agarase gene (dagA) of Streptomyces coelicolor A3(2). Cell 52: 599-607.

Castilho, B.A., P. Olfson, and M.J. Casadaban. 1984. Plasmid insertion mutagenesis and lac gene fusion with mini-Mu bacteriophage transposons. J. Bacteriol. 158: 488-495.

Catron, K.M. and C.A. Schnaitman. 1987. Export of protein in Escherichia coli: A novel mutation in ompC affects expression of other major outer membrane proteins. I. Bacteriol. 169: 4327-4334.

Cavard, D., C. Lazdunski, and S.P. Howard. 1989. The acylated precursor form of the colicin A lysis protein is a natural substrate of the $\operatorname{deg} P$ protease. J. Bacteriol. 171: 6316-6322.

Click, E.M., G.A. McDonald, and C.A. Schnaitman. 1988. Translational control of exported proteins that results from OmpC porin overexpression. I. Bacteriol. 170: 2005-2011.

Craig, E.A. and C.A. Gross. 1991. Is hsp 70 the cellular thermometer. Trends Biochem. Sci. 16: 135-140.

Diedrich, D.L. and J.A. Fralick. 1982. Relationship between the OmpC and LamB proteins of Escherichia coli and its influence on the protein mass of the outer membrane. $/$. Bacteriol. 149: 156-160.

Dodson, M., R. McMacken, and H. Echols. 1989. Specialized nucleoprotein structures at the origin of replication of bacteriophage $\lambda$. I. Biol. Chem. 264: 10719-10725.

Erickson, J.W. and C.A. Gross. 1989. Identification of the $\gamma^{\mathbf{E}}$ subunit of Escherichia coli RNA polymerase: A second alternate $\gamma$ factor involved in high-temperature gene expression. Genes \& Dev. 3: 1462-1471.

Erickson, J.W., V. Vaughn, W.A. Walter, F.C. Neidhart, and C.A. Gross. 1987. Regulation of the promoters and transcripts of $r p o H$, the Escherichia coli heat shock regulatory gene. Genes \& Dev. 1: 419-432.

Forst, S., J. Delgado, G. Ramakrishnan, and M. Inouye. 1988. Regulation of $o m p C$ and $o m p F$ expression in Escherichia coli in the absence of envZ. J. Bacteriol. 170: 5080-5085. 
Givskov, M., L. Olsen, and S. Molin. 1988. Cloning and expression in Escherichia coli of the gene for extracellular Phospholipase Al from Serratia liquefaciens. J. Bacteriol. 170: 5855-5862.

Grodberg, J., M.D. Lundrigan, D.L. Toledo, W.F. Mangel, and J.J. Dunn. 1988. Complete nucleotide sequence and deduced amino acid sequence of the ompT gene of Escherichia coli K12. Nucleic Acids Res. 16: 1209.

Groisman, E.A. and M.J. Casadaban. 1986. Mini-Mu bacteriophage with plasmid replicons for in vivo cloning and lac gene fusion. I. Bacteriol. 168: 357-364.

Gross, C.A., M. Lonetto, and R. Losick. 1992. Bacterial sigmafactors. In Transcriptional regulation (ed. S. McKnight), pp. 129-176. Cold Spring Harbor Laboratory Press, Cold Spring Harbor, New York.

Grossman, A.D., J.W. Erickson, and C.A. Gross. 1984. The htpR gene product of $E$. coli is a sigma-factor for heat-shock promoters. Cell 38: 383-390.

Hirota, Y., H. Sukuki, Y. Nishimura, and S. Yasuda. 1977. On the process of cellular division in Escherichia coli: A mutant of E. coli lacking a murein-lipoprotein. Proc. Natl. Acad. Sci. 74: $1417-1420$.

Hoffmann, H.J., S.K. Lyman, C. Lu, M.-A. Petit, and H. Echols. 1992. Activity of the Hsp70 chaperone complex-DnaK, DnaJ, and GrpE-in initiating phage $\lambda$ DNA replication by sequestering and releasing $\lambda$ P protein. Proc. Natl. Acad. Sci. 89: 12108-12111.

Johnson, K., I. Charles, G. Dougan, D. Pickard, P. O'Gaota, T. Ali, I. Miller, and C. Hormaecha. 1991. The role of a stressresponse protein in Salmonella typhimurium virulence. Mol. Microbiol. 5: 401-407.

Kohara, Y., K. Akiyama, and K. Isono. 1987. The physical map of the whole Escherichia coli chromosome: Application of a new strategy for rapid analysis and sorting of a large genomic library. Cell 50: 495-508.

Kozutsumi, Y., M. Segal, K. Normington, M.-J. Gething, and J. Sambrook. 1988. The presence of malfolded proteins in the endoplasmic reticulum signals the induction of glucose-regulated proteins. Nature 332: $462-464$.

Kumamoto, C.A. 1991. Molecular chaperones and protein translocation across the Escherichia coli inner membrane. Mol. Microbiol. 5: 19-22.

Kumamoto, C.A. and J. Beckwith. 1985. Evidence for specificity at an early step in protein export in Escherichia coli. J. Bacteriol. 163: 267-274.

Landick, R., J. Stewart, and D.N. Lee. 1990. Amino acid changes in conserved regions of the $\beta$-subunit of Escherichia coli RNA polymerase alter transcription pausing and termination. Genes \& Dev. 4: 1623-1636.

Lipinska, B., S. Sharma, and C. Georgopoulos. 1988. Sequence analysis and regulation of the htrA gene of Escherichia coli: A $\sigma^{32}$-independent mechanism of heat-inducible transcription. Nucleic Acids Res. 16: 10053-10067.

Lipinska, B., O. Fayet, L. Baird, and C. Georgopoulos. 1989. Identification, characterization, and mapping of the Escherichia coli htrA gene, whose product is essential for bacterial growth only at elevated temperatures. $J$. Bacteriol. 171: 1574-1584.

Lipinska, B., M. Zylicz, and C. Georgopoulos. 1990. The HtrA (DegP) protein, essential for Escherichia coli survival at high temperatures, is an endopeptidase. J. Bacteriol. 172: 17911797.

Maniatis, T., E.F. Fritsch, and J. Sambrook. 1982. Molecular cloning: A laboratory manual. Cold Spring Harbor Laboratory, Cold Spring Harbor, New York.

Martin, J., A.L. Horwich, and F.U. Harlt. 1992. Prevention of protein denaturation under heat stress by the chaperonin Hsp60. Science 258: 995-998.

Miller, J.H. 1972. Experiments in molecular genetics. Cold Spring Harbor Laboratory, Cold Spring Harbor, New York.

Mizuno, M.-Y., T. Chou, and M. Inouye. 1983. A comparative study on the genes for three porins of the Escherichia coli outer membrane. I. Biol. Chem. 258: 6932-6940.

Mizuno, Z. and S. Mizushima. 1990. Signal transduction and gene regulation through the phosphorylation of the two regulatory components: The molecular basis for the osmotic regulation of the porin genes. Mol. Microbiol. 4: 1077-1082.

Mori, K., A. Sant, K. Kohno, K. Normington, M.-J. Gething, and J.F. Sambrook. 1992. A 22 bp cis-acting element is necessary and sufficient for the induction of the yeast kar2 $(\mathrm{BiP})$ gene by unfolded proteins. EMBO I. 11: 2583-2593.

Neidhardt, F.C. and R.A. VanBogelen. 1987. The heat shock response in Escherichia coli and Salmonella typhimurium. American Society for Microbiology, Washington, D.C.

Pugsley, A.P. 1993. The complete general secretory pathway in gram-negative bacteria. Microbiol. Rev. 7: 50-108.

Ramakrishnan, G., K. Ikenaka, and M. Inouye. 1985. Uncoupling of osmoregulation of the Escherichia coli K12 ompF gene from ompB-dependent transcription. $J$. Bacteriol. 163: 82-87.

Sen, K. and H. Nikaido. 1990. In vitro trimerization of OmpF porin secreted by spheroplasts of Escherichia coli. Proc. Natl. Acad. Sci. 787: 743-747.

Simons, R.W., F. Houman, and N. Kleckner. 1987. Improved single and multicopy lac-based cloning vectors for protein and operon fusions. Gene 53: 85-96.

Singer, M., T.A. Baker, G. Schnitzler, S.M. Deischel, M. Goel, W. Dove, K.J. Jaacks, A.D. Grossman, J.W. Erickson, and C.A. Gross. 1989. A collection of strains containing genetically linked alternating antibiotic resistance elements for genetic mapping of Escherichia coli. Microbiol. Rev. 53: 1-24.

Strauch, K.L. and J. Beckwith. 1988. An Escherichia coli mutation preventing degradation of abnormal periplasmic proteins. Proc. Natl. Acad. Sci. 85: 1576-1580.

Strauch, K.L., K. Johnson, and J. Beckwith. 1989. Characterization of $\operatorname{deg} P$, a gene required for proteolysis in the cell envelope and essential for growth of Escherichia coli at high temperature. J. Bacteriol. 171: 2689-2696.

Straus, D.B., W.A. Walter, and C.A. Gross. 1987. The heat-shock response of $E$. coli is regulated by changes in the concentration of $\sigma^{32}$. Nature 329: 348-351.

1988. Escherichia coli heat shock gene mutants are defective in proteolysis. Genes \& Dev. 2: 1851-1858.

. 1989. The activity of $\sigma^{32}$ is reduced under conditions of excess heat shock protein production in Escherichia coli. Genes \& Dev. 3: 2003-2010.

Wang, Q.P. and J.M. Kaguni. 1989. A novel sigma-factor is involved in expression of the rpoH gene of Escherichia coli. J. Bacteriol. 171: 4248-4253.

Wild, J., E. Altman, T. Yura, and C.A. Gross. 1992a. DnaK and DnaJ heat shock proteins participate in protein export in Escherichia coli. Genes \& Dev. 6: 1165-1172.

Wild, J., A. Kamath-Loeb, E. Ziegelhoffer, M. Lonetto, Y. Kawasaki, and C.A. Gross. 1992b. Partial loss of function mutations in DnaK, the Escherichia coli homologue of the 70$\mathrm{kDa}$ heat shock proteins, affect highly conserved amino acids implicated in ATP binding and hydrolysis. Proc. Natl. Acad. Sci. 89: 7139-7143.

Zylicz, M., D. Ang, K. Liberek, and C. Georgopoulos. 1989. Initiation of $\lambda$ DNA replication with purified host- and bacteriophage-encoded proteins: The role of the $d n a K, d n a I$ and grpE heat shock proteins. EMBO I. 8: 1601-1608. 


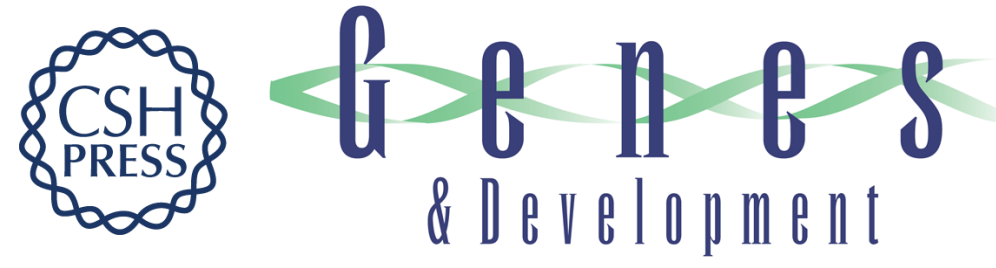

\section{The activity of sigma $E$, an Escherichia coli heat-inducible sigma-factor, is modulated by expression of outer membrane proteins.}

J Mecsas, P E Rouviere, J W Erickson, et al.

Genes Dev. 1993, 7:

Access the most recent version at doi:10.1101/gad.7.12b.2618

References This article cites 52 articles, 32 of which can be accessed free at:

http://genesdev.cshlp.org/content/7/12b/2618.full.html\#ref-list-1

License

Email Alerting Service

Receive free email alerts when new articles cite this article - sign up in the box at the top right corner of the article or click here.

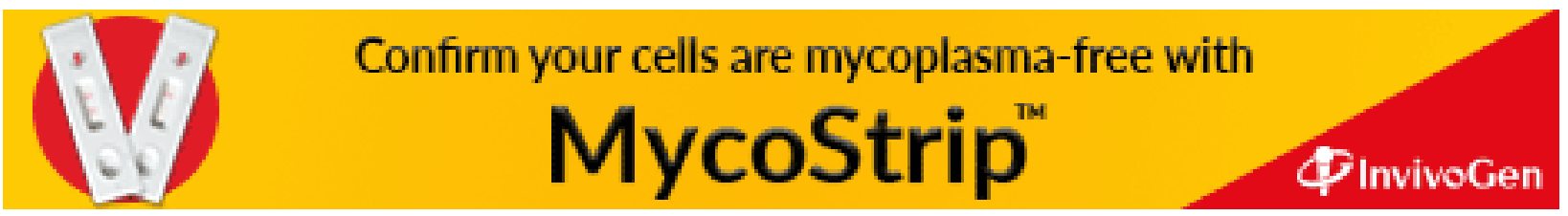

